\title{
Functionality of Special Beer Processes and Potential Health Benefits
}

\author{
Liana Claudia Salanță ${ }^{1}\left(\mathbb{D}\right.$, Teodora Emilia Coldea ${ }^{2, *} \mathbb{*}$, Maria Valentina Ignat ${ }^{2}{ }^{(0)}$, \\ Carmen Rodica Pop ${ }^{1}{ }^{1}$, Maria Tofană ${ }^{1}\left(\mathbb{D}\right.$, Elena Mudura ${ }^{2}\left(\mathbb{D}\right.$, Andrei Borșa ${ }^{2} \mathbb{D}^{\circ}$,

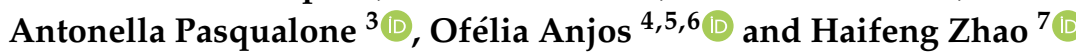

1 Department of Food Science, Faculty of Food Science and Technology, University of Agricultural Sciences and Veterinary Medicine Cluj-Napoca, 400372 Cluj-Napoca, Romania; liana.salanta@usamvcluj.ro (L.C.S.); carmen-rodica.pop@usamvcluj.ro (C.R.P.); maria.tofana@usamvcluj.ro (M.T.)

2 Department of Food Engineering, Faculty of Food Science and Technology, University of Agricultural Sciences and Veterinary Medicine Cluj-Napoca, 400372 Cluj-Napoca, Romania; maria.socaci@usamvcluj.ro (M.V.I.); elena.mudura@usamvcluj.ro (E.M.); andrei.borsa@usamvcluj.ro (A.B.)

3 Department of Soil, Plant and Food Sciences, University of Bari 'Aldo Moro', Via Amendola, 165/A, 70126 Bari, Italy; antonella.pasqualone@uniba.it

4 Instituto Politécnico de Castelo Branco, Escola Superior Agrária, 6001-909 Castelo Branco, Portugal; ofelia@ipcb.pt

5 CEF, Instituto Superior de Agronomia, Universidade de Lisboa, 1349-017 Lisboa, Portugal

6 Spectroscopy and Chromatography Laboratory, Centro de Biotecnologia de Plantas da Beira Interior, 6001-909 Castelo Branco, Portugal

7 School of Food Science and Engineering, South China University of Technology, Guangzhou 510640, China; hfzhao@scut.edu.cn

* Correspondence: teodora.coldea@usamvcluj.ro; Tel.: +40-264-596-384

Received: 23 November 2020; Accepted: 4 December 2020; Published: 7 December 2020 updates

\begin{abstract}
Consumers' demand for functional fermented food that can fulfill nutritional needs and help maintain a balanced diet while also having a positive impact on one's health status is increasing all over the world. Thus, healthy choices could include beverages with nutrients and bioactive compounds which can be used as an effective disease-prevention strategy. Regular beer has certain health benefits which inspire further research with the prospect of obtaining special functional beers with little or no alcohol content. As observed, the special beer market remains highly dynamic and is predicted to expand even further. Therefore, brewers need to keep up with the consumers' interests and needs while designing special beers, namely nonalcoholic beers (NABs), low-alcohol beers (LABs), and craft beers (CBs). Thus, understanding the potential uses of bioactive compounds in special beer, the wide range of therapeutic effects, and the possible mechanisms of action is essential for developing healthier beverages. This review aimed to evaluate the nutritional features of special beers, and their proven or potential beneficial actions on one's health status and in preventing certain diseases.
\end{abstract}

Keywords: beer; process; nonalcoholic beer; low-alcohol beers; craft beer; functional

\section{Introduction}

Beer is a worldwide popular carbonated alcoholic beverage and one of the most consumed alcoholic drinks around the world. The recipes of beer vary across the globe, but modern brewing is very much the same regardless of style [1,2]. Traditionally, beer is made from natural ingredients such as malted cereals: barley (Hordeum vulgare), hops (Humulus lupulus L.), water, and yeast, supplemented or not with other cereals or sources of sugars that are called adjuncts [3-5]. The Czech Republic shows the highest per head consumption, with more than 150 L per year, followed by Austria, Poland, 
and Germany with more than 100 L/head/year [6]. Recently, studies have shown that moderate beer consumption can have anti-inflammatory and antioxidant properties $[7,8]$, presents certain benefits for bone density [9], and may also prevent coronary heart disease [10-12]. Beer compounds that contribute to its functional properties are mainly antioxidants. Polyphenols from malt (70-80\%) and hops (30\%) are the major natural antioxidants in beer [13-15]. Nowadays, special beers, namely nonalcoholic beers (NABs), low-alcohol beers (LABs), as well as craft beers (CBs) contain different amounts of alcohol by volume (ABV) according to each country's regulations. Special beers are popular among consumers' due to prevalent concerns related to health, safety, and legal restrictions or due to the prohibition of alcohol consumption in some countries $[16,17]$. The EU regulations state that beverages containing more than $1.2 \% \mathrm{ABV}$ are free from having a nutrition declaration and a mandatory list of ingredients. Moreover, only beverages containing more than $1.2 \% \mathrm{ABV}$ are required to showcase on their label the actual alcoholic strength by volume $[18,19]$. It is as well worth mentioning that, in the EU, no alcoholic beverages containing more than $1.2 \% \mathrm{ABV}$ are allowed to bear health claims while nutrition claims should refer only to low alcohol levels or to the reduction of alcohol content or energy content [20]. In comparison with regular beer and alcoholic drinks in general, special beers, having under $1.2 \%$ $\mathrm{ABV}$ or no alcohol content, are most of the times less caloric; therefore, at times NAB, LAB, and craft beers might be preferred by individuals who are on a diet aiming for low-calorie intake. As previously mentioned, the maximum alcohol content for beers claiming alcohol-free labels is different according to their country of production. For example, in European countries, alcohol-free beers should not surpass $0.5 \% \mathrm{ABV}$, while in the $\mathrm{UK}$, a NAB needs to have under $0.05 \% \mathrm{ABV}$ [21].

Currently, there is a heightened demand for the development of functional foods and fermented beverages that can fulfill nutritional needs and help maintain a balanced diet while also having a beneficial impact on one's health status [22,23]. The addition of different plants, fruits, or adjuncts in wort or beer has been known for centuries. The medicinal herbs and aromatic plants represent a treasury of bioactive components, which makes them valuable antioxidant raw materials for beer [24,25]. The possibilities are endless when it comes to combining beer with different alcoholic or nonalcoholic beverages: herbs, spices, fruits, honey, sugar, coffee, and other functional compounds [26,27]. However, today's technologies provide methods and offer additional functional properties for the health benefits and sensory properties of regular beer and made beer more accessible to consumers who, till now, avoided beer [28]. The term "functional food or drink" is defined as a nonalcoholic drink, in which the constituents include herbs, vitamins, minerals, amino acids, and vegetables or fruits that provide health benefits beyond its nutritional value [28-30].

This review attempts to shed some light on the nutritional features of special and regular beers in general and on their proven or potential beneficial actions on one's health status and in preventing certain diseases. The main bioactive compounds of such products will be reviewed, and the impact of alcohol consumption will be discussed, showing the potentials of improving the nutritional profile of special beers and their prospective therapeutic properties.

\section{Nutritional Compounds and Health-Related Prospects of Special Beers}

\subsection{Nutritional Features}

The production of special beers including $\mathrm{NAB}, \mathrm{LAB}$, and CBs implies the use of common ingredients processed in different ways and at different concentrations [31]. However, as mentioned previously, key ingredients used to produce special beers include water, malted grain, yeasts, and hops [32]. On the other hand, conventional beers obtained following the German beer purity law (the Reinheitsgebot) can use only malted barley, water, yeast, and hops [33]. Currently, additional ingredients are often added to the basic brewing ingredients, such as lactose, lactic acid bacteria fermented byproducts, fruits, plant extracts, flavorings, coloring agents, sweeteners, and sometimes vitamin C. 
Water is the main component of regular and special beers. Its minerals content has a direct action on the final product's characteristics and different water types are used to obtain different types of beer [34]. The water in Pilsen (Czech Republic), a preeminent and iconic pale lager, contained a low amount of minerals, which directly resulted in its signature pale color and clean bitterness [34]. The water in Burton on Trent in the United Kingdom contains a high level of minerals (e.g., calcium, sulfate, sodium, chloride, and magnesium), and the "hardness" of this water contributes to the unique hoppy bite of English pale ales brewed there (e.g., Bass Ale) (http://www.beersmith.com). Given its high content of water, beer in general can represent a source of hydration. However, although some brewers treat their water with minerals before initiating the brewing process, significantly smaller amounts of minerals are found in the final product.

Generally, beers are obtained using malted barley, which in turn produces sugars during the initial brewing stages. During fermentation processes, these sugars are transformed by yeasts into alcohol and carbon dioxide [35]. Ethyl alcohol and carbon dioxide are the two basic products of alcoholic fermentation carried out by yeast; there are also other metabolic by-products that contribute to the chemical composition and sensorial properties of the products [36]. Moreover, depending on the actual brewing recipe, some of the sugars are still found in the final product. From a nutritional standpoint and considering the prevalence of celiac disease and gluten sensibility, special beers made from grains containing gluten and having gluten in the final product should also be labelled accordingly to inform consumers prior to purchase [37].

In commercial beers, any yeasts still present in the final product are killed through pasteurization to avoid development of pathogenic compounds; however, in craft beers, some probiotic yeasts such as Saccharomyces cerevisiae var. boulardii and S. cerevisiae can be added to enhance the antioxidant activity and polyphenolic profile of beers [38]. Some of the identified phenolic compounds of conventional beers and $N A B$ are represented in Figure 1. However, it was recently suggested that, given the production processes involved in obtaining $\mathrm{NAB}$ and $\mathrm{LAB}$, the phenolic content of such beer types is lower than in ales and lagers [39]. This finding can be explained by the fact that NAB and LAB production frequently involves physical methods such as thermal processes or inverse osmosis, and these processes can trigger the loss and degradation of simple phenols and of isoxanthohumol, a prenylated flavonoid from hops. Moreover, during beer processing, phenolic contents are lowered through trub separation, by their adhesion to yeast cells during fermentation, by elimination during beer conditioning, and by their overall decreasing trend during storage [40]. Also, it was noted that adjusting malting and mashing parameters (increasing the kilning temperature, prolonging the protein rest, and increasing saccharification rest time) is important for increasing the levels of phenolic compounds and antioxidant activity of worts, which will positively impact the beer's quality [41].

Some of polyphenols have been linked to important biological activities, including antioxidant, anticarcinogenic, or antimicrobial activities. Phenolic content and antioxidant activity of the final beer depend especially on the amount and quality of the raw materials used and on the brewing process. A recent study by Nardini et al. [43] showed that the addition of fresh fruits to fermenting beer almost doubled the antioxidant activity of the resulting beer. The addition of fresh fruits during fermentation caused a significant increase in bioactive compounds such as phenolic acids and flavonoids in beer. Fruits brought into beer antioxidants such as carotenoids, tocopherols, and ascorbic acid. These compounds may be responsible for the beer antioxidant activity [43]. There are several examples of studies conducted to find good matches of additional products in beer production which could bring an added content of antioxidants. Another example would be the Beauregard sweet potato beer study which showed increased antioxidant activity especially due to $\beta$-carotene and total phenolic content [44]. 


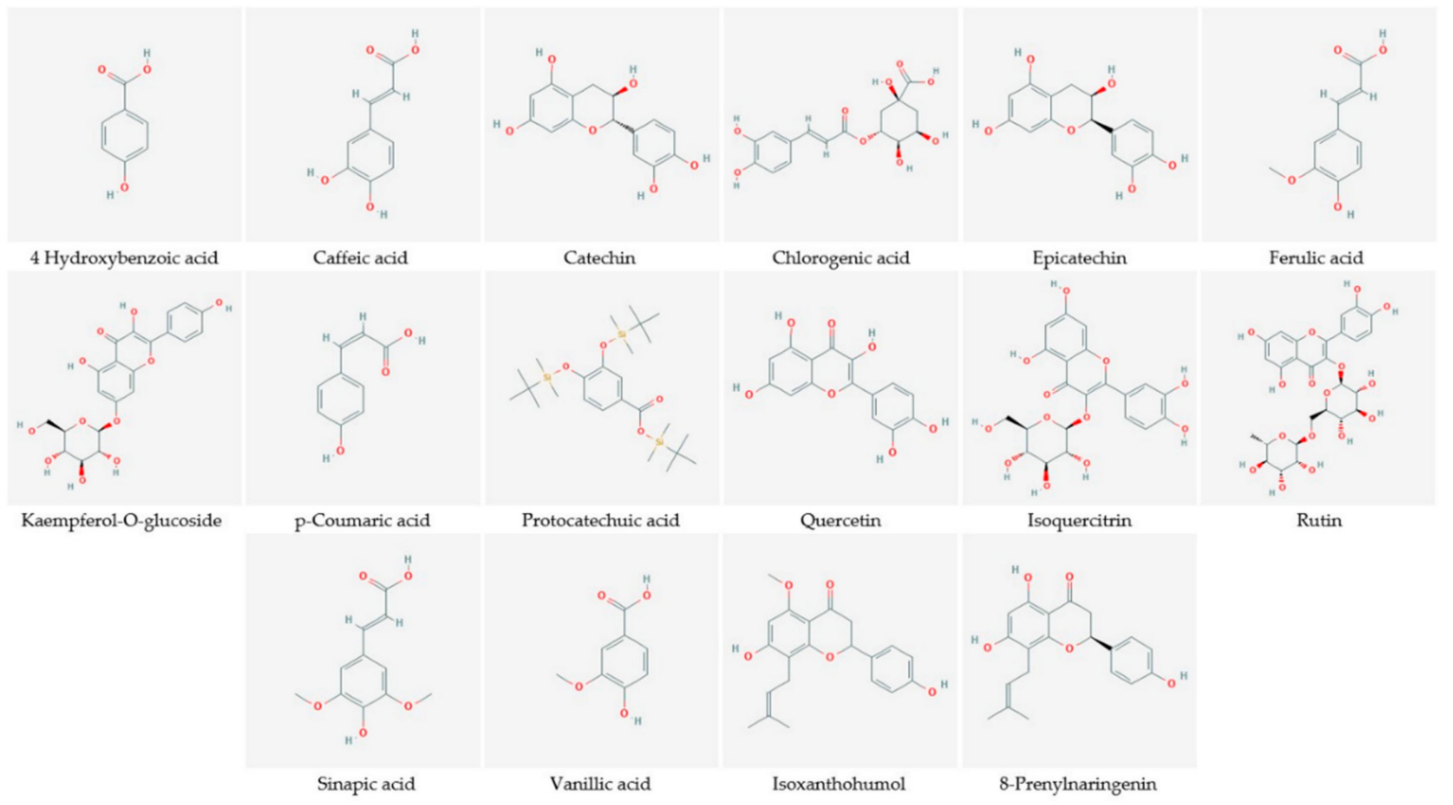

Figure 1. Some of the phenolic compounds of regular beers and nonalcoholic beers (NABs) [42].

Hops are used in beer production as they offer stability, functionality, and a certain bitter taste due to their humulinone and polyphenol contents also having a direct impact on aroma and flavor [45-48]. Moreover, hops can be added as dried leaves, pellets, or hop extracts [49], having as well preservative qualities given their contents in unique bitter acids which can inhibit the growth of gram-positive bacteria $[50,51]$.

At times, lactose is used in the brewing process to heighten the sweet taste as lactose is not consumed by yeasts during fermentation [52,53]. Adding lactose to special beers also provides more body to the final product, as seen in the case of sweet (milk) stout [54]; however, such an ingredient should be highlighted on the ingredients list [55].

Fruits, fruit juices and byproducts, and fruit extracts are often used for making special beer assortments with various flavor, taste, and aroma [56,57]. Adding fruits in special beers offers a heightened content of vitamins and minerals and finally helps regular beers, NAB, LAB, and CB be more nutritionally appealing and have elevated health benefits $[58,59]$. In this sense, it is worth noting that $100 \mathrm{~mL}$ of conventional beer usually contains up to $30 \mathrm{mg}$ of vitamin $\mathrm{C}$ (orange juice contains $22-48 \mathrm{mg} / 100 \mathrm{~mL}$ ), $0.3-0.8 \mathrm{mg}$ of niacin, $0.007-0.17 \mathrm{mg}$ of vitamin B6, 4-60 mcg of folate, $0.3-3 \mathrm{mcg}$ of vitamin B12, and 0.002-0.08 mg of riboflavin. Moreover, beer also contains $\mathrm{K}, \mathrm{Fe}, \mathrm{Zn}$, Se, and small amounts of $\mathrm{Na}[60]$.

Coloring agents are at times added to beers to improve their overall color and appearance and to heighten sensory experience [61]. Most of the time, it is a coloring agent aiming to offer a caramel color and a sweeter taste perception in the case of dark beers [62], like the one used in cola, sauces, foods for pets, or vinegars. Nevertheless, other coloring agents can be used as well for obtaining special beer. For example, a study conducted on Czech beers served in restaurants during the Easter holiday showed that 8 beer samples out of the 11 samples contained artificial colorants (tartrazine and brilliant blue FCF); however, their concentrations did not show a serious risk for consumers' health [63]. Such coloring agents should be highlighted as well on the ingredients list. Although these additives have little to no impact on the nutritional profile of beers, some producers and craft beer brewers would opt for using organic pigments which in turn might elevate the product's healthy appeal, as seen in the case of a Aronia-infused beer [64] or in the case of Mexican pigmented corn beers [65].

As previously mentioned, vitamin $C$ is sometimes added to beers [66] and is most of the time listed as ascorbic acid on the product's nutrition facts label. Although conventional beer already is at 
a certain degree a natural source of vitamins and minerals, some brewers try to follow the current trend of making alcohol-free drinks and products as healthy and nutritious as possible.

\subsection{Proteins}

The polymeric fraction of NABs usually contains proteins, polyphenols, and polysaccharides [67]. Studies point out that various processes involved in the production technology affect the protein contents of beer and that most brewers would aim to preserve beer colloidal stability by remove haze-active materials such as proteins.

Through conditioning-maturation, clarification, and stabilization processes, yeast and haze loading materials are generally reduced. For example, brewing processes such as wort boiling lead to coagulation of proteins and their loss through "whirlpools"; during the fermentation step, the $\mathrm{PH}$ decreases and proteinic particles are then separated by sedimentation; and during the beer's maturation process, the proteins adhere to yeast particles and are then discarded [68]. Once again, different beer types contain different amounts of nutritional compounds. Protein distribution and amino acid content of beers vary depending on the raw materials and enzymatic reactions used in beer technology [69]. For example, Dutch beers with $0.0 \% \mathrm{ABV}$ are reported to contain $0.3 \mathrm{~g}$ protein $/ 100 \mathrm{~mL}$ while regular beers $(5 \% \mathrm{ABV})$ contain $0.5 \mathrm{~g}$ protein $/ 100 \mathrm{~mL}$ [70]. It was also estimated that, after ingesting $1 \mathrm{~L}$ of regular beer over the course of 1 day, male and female individuals (age 25-50) would benefit from 5-10 g proteins [71]. Similarly, nonalcoholic malt drinks such as nonalcoholic lagers and nonalcoholic wheat beers $(<0.5 \% \mathrm{ABV})$ have protein contents of $0.3-0.6 \mathrm{~g} / 100 \mathrm{~mL}$. Given this data, beers in general, regardless of their alcohol content, would have similar protein contents, although there are exceptions to the rule as seen in the case of various beer types such as lager, ale, and wheat beer, where proteins are usually lacking [72].

\subsection{Lipids}

Beer contains lipids as well, such as fatty acids. Moreover, the variety of raw materials and the brewing processes implied for obtaining beer are strongly linked to the compounds of the final beer. Depending on the malt's composition and the lauter's turbidity, during the brewing process, multiple lipid types can result, such as simple (e.g., triacylglycerols, diacylglycerols, monoacylglycerols, and free fatty acids), complex (e.g., phospholipids and sphingolipids), and covalently bound lipids [73].

Lipids present in wort and beer are of particular importance given that they affect yeast growth and metabolism while impacting foam-stability as well. It was thus shown that barley lipids have adverse effects on beer quality although long-chain fatty acids possess high flavor potential. Even though several long-chain fatty acids have been described as precursors for specific flavors, there are indications that certain lipids may unfavorably affect beer quality. Flavors linked to beer aging have been attributed to the oxidative degradation of linoleic and linolenic acids during the fermentation process, as seen in the case of trans-2-nonenal, one of the more frequently recognized flavor compounds derived from lipid oxidation [73].

Even if fatty acids are only small constituents of beer, their presence influences beer quality in both positive and negative ways. Medium-chain fatty acids like hexaconic, octanoic, and decanoic acids are formed by yeasts during fermentation, and their development is influenced by yeast strain, original gravity, wort composition, and degree of aeration [74].

The content and type of lipids employed in the brewing process are influenced by the raw materials used. Replacing a part of malt with unmalted materials is a common practice, and further studies are still being developed to understand the impact of lipids in beer production. For example, using unmalted pseudocereals like quinoa and amaranth was shown to result in a favorable influence on the amino acids and fatty acids profiles. Finally, the type and concentration of individual amino acids and fatty acids in the fermented wort substantially influence the flavor compounds synthesized by yeast; thus, differences in the profiles of esters and higher alcohol have been reported in beers produced with pseudocereals [75]. 
The germination of barley and the mashing process can result in the loss of lipid contents originally found in barley and malt due to the release of fatty acids via the hydrolysis of triglycerides, which are then metabolized. The resulting fatty acids, and mono- and diglycerides do not accumulate in the malt and are found only in trace amounts in the finished product. Although some brewers put efforts into minimizing and controlling the lipid content of raw materials and of the final product, brewing by-products are nevertheless looked at as potential sources of novel functional products. Such an example is the assessment of antithrombotic properties and fatty acid composition of lipid extracts sampled at various stages of the brewing process [76,77].

\subsection{Carbohydrates}

Although NABs generally do not contain fats, they contain considerable amounts of carbohydrates, some of which are sugars left over after fermentation processes, contributing to the caloric value of beers [78]. The carbohydrate content of regular beers is 3.3-4.4 g/100 mL, and it mainly consists of dextrins, followed by monosaccharides, oligosaccharides, $\beta$-glucans, and arabinoxylans [79]. Depending on the grains used and depending on the brewing process overall, special beers have variable contents of carbohydrates. For example, nonalcoholic malt drinks such as nonalcoholic lager and nonalcoholic wheat beers $(<0.25-<0.5 \% v / v)$ contain carbohydrates ranging between $4.5-14 \mathrm{~g} / 100$ $\mathrm{mL}$, of which 1.3-11.4 g are sugars per $100 \mathrm{~mL}$ [72]. In comparison, conventional beers such as porter and stouts are reported as having above $20 \mathrm{~g}$ of carbohydrate per pint (approximately $568 \mathrm{~mL}$ ) [60] or $58.65 \pm 1.66 \mathrm{mg} / \mathrm{mL}$ of carbohydrates [80]. Carbohydrates, although provide energy, can influence one's glycemia; therefore, a person suffering from diabetes should be completely aware of the carbohydrate content of regular and special beers.

\subsection{Energy Value}

The energy value of beer is estimated based on total alcohol $(7 \mathrm{kcal} / \mathrm{g})$, total carbohydrates $(4 \mathrm{kcal} / \mathrm{g})$, total amino acids $(4 \mathrm{kcal} / \mathrm{g})$, and total organic acids $(4 \mathrm{kcal} / \mathrm{g})$. A study conducted on beer samples obtained from a craft brewery estimated the caloric content and different organic compounds. The calculated energy value of the craft beer samples indicated an interval of $417-709 \mathrm{kcal} / \mathrm{L}$, with samples of amber ale having the lower caloric value and of Scotch ale having the highest caloric value [81]. On the other hand, regular beers with $4 \% \mathrm{ABV}$ contain $105 \mathrm{kcal} / 350 \mathrm{~mL}$ [82]. It is mandatory to be aware of the nutritional guidelines and calorie intake recommendations when having beer as a regular part of an individual's eating and drinking habits. In what concerns the European population, it was advised by the European Food Safety Authority (EFSA) that the daily average requirement of calorie intake to satisfy the physiological requirement or metabolic demand of individuals with a moderately active lifestyle should be of 2149 to $2054 \mathrm{kcal}$ for women between 18 to 49 years old and of 2.674 to $2555 \mathrm{kcal}$ for men between 18 to 49 years old [83].

Beer is a source of energy and contributes significantly to daily calories intake. The main calory sources of beer are represented by carbohydrates and alcohol. Compared with lager or beer mixes, nonalcoholic beers have lower alcohol content $(<0.2 \%)$ and, therefore, are also most of the times evidenced with a lower energy values [84]. Special beers such as NAB, LAB, and CB contain small amounts of ethanol. This alcohol content, although smaller than in regular beers, provides energy upon intake, with the conversion factor for alcohol being $7 \mathrm{kcal} / \mathrm{g}$ [85].

\subsection{Safety Concerns for Beer Consumption}

Certain beer compounds, such as metal mineral elements, can negatively impact consumers' health. Given this, heavy metals like $\mathrm{As}, \mathrm{Pb}, \mathrm{Fe}$, and $\mathrm{Cd}$ are strictly controlled in relation to the overall beer production process and contact materials, meaning processing equipment, additives, and storage materials. Regarding the metal contents measured in beer, the most important aspect is to be under the recommended threshold for drinking water, given that a beer's content is $90 \%$ water [86]. 
As previously mentioned, beer's ethanol content is the most concerning element given that its excessive consumption wields damaging effects on consumers' health, showing heightened illness threats on several organs, and is linked to social issues such as accidents, addiction, crime, and violence [9]. It is known that excessive consumption of beer and of any other alcoholic drink is harmful to one's wellbeing and should be used in moderation. Increasing evidence, which will be later presented, shows that moderate beer consumption might still be beneficial at times, mainly due to beer's bioactive compounds.

However, it is speculated that moderate alcohol consumption brings some beneficial health effects on the cardiovascular system [87]. A lowering of coronary diseases by $30-40 \%$ was observed in moderate drinking compared to the nondrinking population [88]. A recent study specified that a volume of $330 \mathrm{~mL}$ of alcoholic beer positively contributes to the changing in lipid profile and insulin sensitivity of adult men [89]. It was also pointed out that a complex interaction between polyphenols and gut microbiota plays an important role on health benefits when drinking moderate beer quantities [90].

\subsection{Raw Material Influence and Brewing Process Impact on Beer Functionality and Its Compounds}

The trend followed by consumers is to reduce alcohol, gluten, sugar, and carbohydrates in beer and to increase the antioxidants and polyphenols in the final product but without spoiling the enjoyment of beer's traditional taste [37,91].

Bibliographic studies reported relevant correlations between the level polyphenols and the antioxidant activity in beers [92,93]. Barley malt has an average of $50-100 \mathrm{mg} / 100 \mathrm{~g}$ of polyphenols, but it holds significantly high contents of some varieties. So far, it has been mainly suggested that dark beers and dark malts possess a considerably higher content of polyphenols and antioxidative activity than pale beers $[13,94,95]$; however, special malts can be further designed for obtaining elevated contents of polyphenols in NABs and LABs, which would provide optimum health traits. Schwarz et al. [96] studies on the influence of mashing over polyphenol availability indicate that $40-45{ }^{\circ} \mathrm{C}$ is the ideal temperature for phenolic acid release from malt, until the end of the first enzymatic rest, an interval optimal also for release of antioxidants bound to cell walls, proteins, or polysaccharides through the activity of protease and b-glucanase enzymes [15]. Furthermore, Zhao [97] analyzed the profile of phenolic compounds from barley to the final product and reported that their amount had generally increased significantly during malting and mashing but decreased during the fermentation and storage processes [97], whereas authors like Pascoe et al. [98] observed an increase in levels of antioxidant activity after mashing, boiling (during Maillard reaction and after polyphenols from hops are dissolved in the wort), fermentation, and chill-lagering and a decrease after beer filtration [98]. Fumi et al. [99] observed a general reduction of phenolic content by $50 \%$ than that initially found in malt over the entire brewing process, analyzing all the technological steps, the most important being during the mashing and boiling process due to the high temperatures involved [99]. By analyzing the polyphenol level fluctuation within the brewing process, we can conclude that selecting the appropriate raw materials influences significantly the antioxidants in the final product due to the initial intake. To transfer them as much as possible to the final product, the optimum saccharification temperatures must be applied during the early stages of mashing, when antioxidants are released to the highest extent, and further improves the antioxidant potential of the wort through adequate hop boiling, since hops also come with a high intake of polyphenols. As previously mentioned, hops represent about $30 \%$ of the polyphonic content present in beer, and one of the most important polyphenols of hops are represented by xanthohumol [100]. Recent studies confirm the possibility of increasing the antioxidant capacity and functionality of beer even further by adding ingredients rich in functional compounds, such as Aronia, goji, or extracts of thyme-Thymus vulgaris—or lemon balm-Melissa officinalis [101]. Ducruet et al. [102] studied the effects on the addition of $50 \mathrm{~g} / \mathrm{L}$ of goji berries to an amber ale beer in different stages of the brewing process and in different forms (grounded, whole) using Trolox Equivalent Antioxidant Capacity (TEAC) and Oxygen Radical 
Absorbance Capacity (ORAC) assays. They revealed a significant increase in antioxidant capacity in the final test product, correlated with an increased TEAC value by approximately $30 \%$ for the beer samples that had berry added before the first or the second stages of fermentation and an improvement that reached more than $60 \%$ for the TEAC value and almost $80 \%$ for the ORAC value for the samples that had berry added before the wort boiling. Most of the samples increased substantially the content of both phenolic acids (p-coumaric and ferulic acids) up to almost $8 \mathrm{mg} / \mathrm{L}$; were characterized by lower turbidity, high color intensity, special coffee-like taste, high content of bioactives such as rutin and 2-O- $\beta$-D-glucopyranosyl-L-ascorbic acid; and were accepted by test consumers [102]. Moreover, as briefly mentioned previously, in addition to antioxidant attributes, fruits can enrich beers with phenolic acids such as caffeic, ferulic, p-coumaric, and vanillic acids, which have been extensively documented for their anti-inflammatory, cardioprotective, neuroprotective, antimicrobial, antiviral, and anticancer activities [103,104].

According to the European Commission guidelines, the gluten-free label can be ascribed to beers made from pseudocereal malts and atypical gluten-free (GF) cereal malts and beers made from typical brewing malts and other malts containing gluten, which have been technologically processed to reduce the gluten level to no more than $20 \mathrm{mg} / \mathrm{kg}$. We can also define very-low-gluten beer as beer made from brewing malts which have undergone special technological processing to reduce the level of gluten to no more than $20-100 \mathrm{mg} / \mathrm{kg}$ [105].

In order to obtain gluten-free (GF) functional beer which has less than $20 \mathrm{mg} / \mathrm{kg}$ and can be safely consumed by people with celiac disease, there are several techniques available that can be classified into two large categories: one focused on raw materials applied and the second focused on process engineering. The raw materials include natural GF cereals (rice, maize, sorghum, and millet) and pseudocereals (amaranth, buckwheat, and quinoa) that can enhance the special brews with their antioxidative activity (rutin from buckwheat and tocopherol from quinoa) and bioactive polysaccharides from quinoa [106-108]. Including these in the mashing process comes with several disadvantages that have to be taken into account, like different grain consistency, lower content in carbohydrates in pseudocereals [109,110], higher gelatinization temperature, low enzymatic capacity [111], the need for a different specific diagram, and several small investments in order to control the enzymatic activity [112]. The main disadvantage is that the flavor of the beers made from GF grains is different from regular barley beer, which can provide a negative sensation to consumers [91], but still can be concealed with aromas from different herbs or fruits. In the raw category, we can include the traditional gluten-containing cereals (barley and grain) that can be stripped of gluten through different breeding techniques, including mutagenesis, transgenesis, or genome editing [113], but these need to overcome consumer acceptance and accede to present legislations. Through process engineering, the barley malt that contains gluten less than $20 \mathrm{mg} / \mathrm{kg}$ can be obtained via enzymatic degradation, using exogenous enzymes such as transglutaminase and prolyl endopeptidase [114], but for this innovative technique to be implemented, it is necessary for the brewers to have profound knowledge of the composition of the beer matrix corroborated with the whole brewing process and good control of the enzymatic process. These processes encounter similar implementation problems like genetic breeding.

To obtain beers low in sugars and alcohol, the initial carbohydrate intake must be controlled and the mashing must be very efficient so that most of the starch is broken down to simple molecules that are accessible to yeast. Complex nonfermentable carbohydrates like dextrins and limit dextrins are not easily fermented and remain in the beer, are nevertheless caloric, and can be hydrolyzed into glucose during digestion in the human body and consequently absorbed into the bloodstream [115]. Technological steps of brewing low-calorie beers, so-called Light beers, focus on glucoamylase and dextrinases. The latter are of great utility in dealing through the mashing process with the dextrins surviving because of the limited action of limit dextrinase [28]. Beers with fewer calories and with less alcohol have considerably lower levels of phenols than regular lagers and dark beers [116]; potential flavor deficiencies characterized by enhanced sweetness; reduced bitterness; and above all, a significant lack of mouthfeel. Nonetheless, a well-balanced and full beer flavor can be obtained by the addition of 
flavor substances from specialty malts, providing enhanced hop character and the addition of a low level of priming syrup [37].

The concept of functionality and healthiness of a product is attributed due to its beneficial bioactive compounds. As previously mentioned, the selection for raw materials to be used in beer production and the careful planning of the brewing process have a direct impact on beer functionality and its bioactive compounds.

Various actions can be taken regarding the change of raw materials used for obtaining functional special beer, as it was seen in the case of cornelian cherry sour nonalcoholic beers brewed with Saccharomycodes ludwigii [56]. The resulting beers had several times higher antioxidative potential and significantly higher polyphenols concentration compared to the control ones and a low energy value of $116-148 \mathrm{kcal} / 500 \mathrm{~mL}$ of beer. Moreover, the special beer samples were rich in anthocyanins and iridoids and presented novel sensory attributes. Another example of a positive fruit intervention in beer production is the case of beer enriched by macerating quince fruits. Adding quince to the process of obtaining regular beer enhanced the total polyphenol content, the total hydroxycinnamic acids, and the main volatile compounds linked to fruity sensory descriptors and resulted in superior intensities of floral and fruity sensory attributes. Moreover, the quince beer also scored higher in functionality and sensory profile than the control beer [117].

The mineral and metal contents of beer are a continuous subject of research, and choosing the right raw materials is once again one of the key points in controlling the final product's profile. A study investigated the impact of raising the share of unmalted barley and spelt, which are used as adjuncts (5-30\%), and the effect of the mineral content of water on the wort concentration of metal ions (calcium, magnesium, zinc, and manganese). It turned out that spelt may be a valuable raw material for obtaining worts with required mineral composition, which also improves the sensory characteristics of the finished product given the lower contents of manganese ions [118]. Moreover, along the importance of raw materials, it was shown that, although the wort composition and its preparation are of utmost importance for dictating a beer's quality, the fermentation step is the one that determines the final beer flavor, an important aspect to take note of when trying to obtain both a healthy and sensory appealing beverage [119].

As seen so far, the complex composition of beer can be ascribed to the presence of various classes of compounds, some of which originate from the raw materials, while others develop through interactions and reactions during the brewing process. These components can influence the beverage in a variety of aspects, from its flavor to its foaming ability and its safe consumption. Regrettably, as observed, there is a lack of advanced analytical techniques used in routine brewing processes due to the high initial cost of analytical instruments and to the required qualified human resource to operate them. However, the extensive insertion of MALDI-TOF-MS to the brewing scene would help to categorize beers according to their microbial content, while the ability of GC-VUV to separate and quantify terpenes can improve the marketability of particular hops and hoppy beers [120].

Obtaining healthy and functional beers with an attractive sensory profile implies assuring that the final product has little to no alcohol content as well while other important compounds are to be kept in amounts superior to those found in regular beers. There are various methods of obtaining alcohol-free beers, and each process has its benefits and drawbacks which make the brewing design more delicate. Dealcoholization methods can be organized into either "biological" or "physical" categories, whereby biological subcategories employ preprocessing methods and physical subcategories employ postprocessing methods [40]. As some would claim, perhaps one of the most promising methods to obtain NABs is the cold contact process, one of the methods used in the inhibition of alcohol formation [16]; however, further research is required.

\section{Health Features of Special Beers}

Conventional beers are a particularly complex blend of bioactive substances [121]. Similarly, beers with a low alcohol content $(<0.5 \% \mathrm{ABV})$ are a reliable source of nutrients like vitamins, minerals, 
soluble fibers, polyphenols, and flavonoids. As discussed in the previous section, beers with a small $\mathrm{ABV}$ or NABs can be obtained through dialysis, reverse osmosis, vacuum rectification and evaporation, use of biological processes such as controlled or suppressed alcohol formation, use of special yeasts, and the cold contact process [21]. While lacking high contents of alcohol, such beverages can be more nutritious and potentially functional. In this regard, a study published in 2018 showed that nonalcoholic lagers and nonalcoholic wheat beers $(<0.25-<0.5 \% \mathrm{ABV})$ have different concentrations of $\beta$-sitosterol, $\beta$-sitosterol- $\beta$-D-glucoside, campesterol, and stigmasterol while lack ergosterol and brassicasterol. Moreover, it was reported that these NABs would have an energy value of $20-59 \mathrm{kcal} / 200 \mathrm{~mL}$, being fat and fiber-free [72].

The moderate consumption of regular beer is continuously encouraged by various studies [58]. For example, a recent study evaluating the content of polyphenolic compounds in industrially produced beers such as lager, pilsner, black, and dark beer concluded that the moderate consumption of black beers would bring a heightened polyphenolic content, thus contributing to the consumer's health. Black beer was shown to contain $14.22 \mathrm{mg} / 10 \mathrm{~mL}$ of gallic acid, beer's predominant phenolic acid [122].

On the other hand, as briefly mentioned, beer also provides macroelements; 52 samples of conventional beer produced in Armenia, China, Czech Republic, Germany, Ireland, Italy, Mexico, Portugal, Thailand, Ukraine, and Vietnam were evaluated for their value as a source of macroelements. It was then concluded that $500 \mathrm{~mL}$ of beer comprises up to $12 \%$ of the daily Ca norm of the National Food and Nutrition Institute of Poland and up to $15.5 \%$ of the US norms. The rest of the studied elements such as $\mathrm{Cl}, \mathrm{K}$, and $\mathrm{P}$ represent $3 \%$ of the daily need [123]. Correspondingly, another study confirmed that nonalcoholic beers also contain minerals such as $\mathrm{P}, \mathrm{S}, \mathrm{Cl}, \mathrm{K}$, and $\mathrm{Ca}$ [86].

As well-known, mineral elements are particularly important for human health. Mineral elements must be obtained through diet because they cannot be synthesized in the human body. These compounds can be found in different kinds of foods and beverages and are commonly separated in major elements (e.g., $\mathrm{Ca}, \mathrm{K}, \mathrm{N}, \mathrm{Mg}, \mathrm{Na}, \mathrm{Cl}, \mathrm{P}$, and $\mathrm{S}$ ) and minor and trace elements (e.g., $\mathrm{Fe}, \mathrm{I}, \mathrm{B}, \mathrm{Br}$, and $\mathrm{Si}$ ). However, the ingestion of mineral must be made carefully because some of them can be toxic if the consumption is overly high or prolonged (e.g., $\mathrm{Zn}, \mathrm{Se}, \mathrm{Mn}$, and Mo) [124].

\subsection{Positive Action at Cardiovascular Level}

Beer contains antioxidant compounds mainly represented by phenolic compounds and melanoidins [13]. Polyphenols are described by having in their structure one or several phenolic groups capable of reducing reactive oxygen species and various organic substrates and minerals. These properties justify the substantial interest in their preventive role for major chronic diseases associated with oxidative stress like cancers, cardiovascular diseases (CVD), neurodegenerative diseases, osteoporosis, or type II diabetes [125]. Thus, beer phenols were shown to help lower blood pressure and to reduce the risk of cardiovascular disease by heightening the concentration of nitric oxide in the plasma [87]. NAB consumption is thought to have positive action on a cardiovascular level as a cross-sectional study has shown that healthy people drink more of it than people suffering from cardiovascular disease. Moreover, people free of CVD have more fruits and olive oil in their daily meals [126].

The hemostatic actions of conventional beer, $\mathrm{NAB}$, and ethanol/water $(v / v / 4 \%)$ were analyzed in a study of acute consumption in 12 young healthy volunteers (19-36 years old) who drank $3 \mathrm{~L}$ over the course of $3 \mathrm{~h}$. The results indicated that the acute consumption of each beverage lowered the expression of activated fibrinogen receptor, the platelet activation marker CD62, and the formation of monocyte-platelet-aggregate. Furthermore, it was indicated that consuming NABs results in significant inhibitory actions on thrombin generation while beer and ethanol consumption trigger procoagulant action [127]. This suggests that dealcoholized beer can deliver cardiovascular benefits minus the damaging effects of alcohol.

There is the prospect to develop the bioactive characteristics of beer while decreasing ABV and energy through innovative production designs over the use of ingredients, brewing methods, 
and fermentation types [60]. Such enhancements to beer can lead to its development as a functional, nutritious, and potentially therapeutic beverage. For example, the results of a small randomized clinical trial published in 2015 strengthens the idea that consuming alcohol-free beers and regular beers reduces overall cardiovascular risk markers. The 36 male participants (55-75 years old) were moderate drinkers with a high risk of CVD. Beer, NAB, and gin were given for consumption over six sequences of interventions lasting 4 weeks each. The results indicated that the phenolic content of NAB and of regular beer reduces leukocyte adhesion molecules and inflammatory biomarkers, while alcohol consumption on its own mainly enhances the lipid profile and lowers plasma inflammatory biomarkers related to atherosclerosis [128].

A few years ago, NAB consumption was evaluated for its effect in atherosclerosis-related factors such as lipid profile, oxidative stress parameters, and proinflammatory cytokines in 29 postmenopausal women. Thus, a study published in 2009 indicated that the consumption of NAB $0 \% \mathrm{ABV}(500 \mathrm{~mL} / 45$ days) results in decreased oxidative stress with a potentially positive impact on a cardiovascular level [129]. Finally, NAB can be included in one's diet for its preventive action in diseases related to oxidative stress; however, further clinical studies are needed to illustrate the long-term effects on cardiovascular disease from regular NAB consumption.

A prospective 8-week intervention study examined on a cardiovascular level the outcomes of moderate consumption of alcohol-free beer or traditional beer on anthropometrical and biochemical parameters, liver and kidney function biomarkers, and vascular endothelial function in obese individuals having no other CVD risks. During the 2 intervention periods (4 weeks/intervention) men were instructed to drink 2 cans of traditional beer daily $(660 \mathrm{~mL}$ conventional Spanish beer having $30 \mathrm{~g}$ ethanol and $1208 \mathrm{mg}$ polyphenols) or 2 cans of $\mathrm{NAB} /$ day $(660 \mathrm{~mL}$ having $0 \mathrm{~g}$ ethanol and $828 \mathrm{mg}$ polyphenols), while women drank 1 can of conventional beer daily ( $330 \mathrm{~mL}$ having $15 \mathrm{~g}$ ethanol and $604 \mathrm{mg}$ of polyphenols) or 1 can of NAB ( $330 \mathrm{~mL}$ having $0 \mathrm{~g}$ ethanol and $414 \mathrm{mg}$ of polyphenols). It was concluded that moderate conventional beer and NAB consumption neither lead to additional weight gain in otherwise healthy and obese individuals nor result in damaging effects over their health, such as vascular endothelial dysfunction or stiffness. By contrast, the moderate consumption of conventional beer was linked to enhanced antioxidative properties of HDL, promoting cholesterol efflux, which can inhibit lipid deposition in the vessel wall [42].

\subsection{Chemoprevention}

Chemoprevention can be described as the use of safe natural compounds and synthetic chemicals meant to intervene in multistage carcinogenesis. Reducing the risk of developing cancer can be achieved in various ways, such as through diet modification and frequent consumption of plant-based foods [130].

In a review article published in 2005, it was stated that in vitro experiments demonstrated the cancer chemopreventive effects of hop-derived prenylflavonoids and of humulone, adding that further in vivo studies are needed to assess the bioavailability, distribution, effectiveness, and safety of beer's bioactive compounds in long-term animal models [121].

Another review article published in 2012 suggested that light to moderate consumption of beer can result in antimutagenic and anticarcinogenic effects given its content in phenolics, pseudouridine, spongouridine, glycine betaine, melanoidins, and dietary fiber, which in turn might act beneficially through their antioxidant effect, modulation of carcinogen metabolism, anti-inflammatory effects, and enhanced intestinal secretion [71].

The effects of four main hop-derived prenylflavonoids (xanthohumol, isoxanthohumol, 6-prenylnaringenin, and 8-prenylnaringenin) were investigated in an in vitro study for their actions in chemotherapy for colorectal cancer. It was shown that all the studied prenylflavonoids have significant anticancer potential, especially xanthohumol, which showed IC50 values ranging from 3.6 to $7.3 \mu \mathrm{M}$ in proliferating colon cancer cells. Moreover, the results indicated that beer consumption should be avoided during chemotherapy with 5-fluorouracil, oxaliplatin, and irinotecan given 
that xanthohumol and isoxanthohumol, beer's most abundant prenylflavonoids, antagonized the chemotherapy's antiproliferative effects. Nevertheless, 6-prenylnaringenin acted synergistically with irinotecan; therefore, it should be further investigated for a combination therapy [100].

Previously, Vanhoecke et al. [131] noted that xanthohumol also acts in vitro on human breast cancer cells and that it should be further researched as it showed potential as a therapeutic drug in cancer, decreasing the number of invasive cancer cells. Nevertheless, it is important to note that drinking conventional beer, NAB, LAB, or craft beers will provide only low concentrations of xanthohumol (5-800 $\mu \mathrm{g} / \mathrm{L})$ due to the fact that, during the brewing process, xanthohumol is mainly converted to isoxanthohumol, its flavone isomer.

Other compounds of interest for their impact on cancer are $\beta$-glucans, complex polysaccharides present in barley. In a clinical phase, a study published in 2013, barley-derived $\beta$-glucans were evaluated in treating chemoresistant neuroblastoma. The barley-derived (1 to 3),(1 to 4)- $\beta$-D-glucan (BD) was administered orally in rising doses from 10 to $80 \mathrm{mg} / \mathrm{kg} /$ day for 10 days, along with 3F8 (fixed dose of $10 \mathrm{mg} / \mathrm{m}^{2} /$ day), a murine anti-GD2 antibody, to four cohorts of six patients having recurrent or refractory advanced-stage neuroblastoma. The results indicated that 3F8 coupled with BG was well endured and exhibited antineoplastic action in recurrent or refractory advanced-stage neuroblastoma patients. Nevertheless, it was concluded that additional clinical studies of this innovative combinatorial immunotherapeutic treatment are necessary [132].

\subsection{Other Health Benefits of Beers Having Little to $0 \% A B V$}

In what concerns the consumption of beers having very little alcohol levels, just recently, it was concluded that moderate consumption of lager NAB $(0.5 \% \mathrm{ABV})$ results in positive action on one's health most likely due to its content of biological active polyphenols and phenolic acids, also enriching gut microbiota with beneficial bacteria. The study focused on 2 groups, one consisting in 35 adults ( $40 \%$ women and $60 \%$ men) with a mean age of 28.7 years drinking $355 \mathrm{~mL}$ of NAB/day for 30 days and the other group had 33 adults (45\% women and 55\% men) having a mean age of 29.7 years who drank the same amount of conventional lager beer $(4.9 \% \mathrm{ABV})$ for the same amount of days. More specifically, the consumption of NAB reduced fasting blood serum glucose and increased functional $\beta$ cells while the consumption of regular beer resulted in opposite effects [133].

Moreover, the consumption of NAB $(0.9 \% \mathrm{ABV})$ also seems to have protective action over learning and memory abilities. A study published in 2018 by Merino et al. [134] on aluminum nitrate intoxicated rats concluded that $\mathrm{NAB}$, silicon, and hydroalcoholic hop extracts can block and reduce the deleterious effects of aluminum on the in vivo antioxidant and inflammatory statuses. It was stated that feeding the intoxicated rats with $\mathrm{NAB}$ ( $5 \mathrm{~mL}$ of $\mathrm{NAB} /$ day, equivalent to moderate/high consumption in humans) can prevent some neurodegenerative events caused by aluminum intoxication, probably by contributing with antioxidants (e.g., phenolic compounds, flavonoids, and tannins) or by modulating antioxidant enzyme expressions. Nevertheless, further studies are required to confirm these findings given that this study was conducted only over the course of 3 months, inducing neurological damage using only one dose of aluminum nitrate, testing just a single dose of NAB, hop extracts, or silicon, all tests being done only on young male rats [134].

Besides being evaluated for their prevention or therapy-related actions in various illnesses, various beer types are also assessed for their impact on the health status of people with active lifestyles. For example, in 2018 , there was a study published on the effects of NAB $(0 \% \mathrm{ABV})$ on fluid and electrolyte homeostasis in athletes. Seven male soccer players with similar training and competitive schedules ingested $0.7 \mathrm{~L}$ of alcohol-free beer $45 \mathrm{~min}$ before performing a 45 -min treadmill running session at $65 \%$ of the maximal heart rate. The athletes participated in three trials completed in a randomized order and separated by minimum 1 week. The results indicated that the consumption of beer having $0 \% \mathrm{ABV}$ can help maintain blood electrolyte homeostasis during exercise and therefore can be consumed as an effective sports drink. However, the study also covered the same amount of water 
and regular beer consumption, and it turned out that these presented inferior benefits, with regular beer negatively impacting sport performance and health [135].

Given the variety of compounds within $\mathrm{NAB}, \mathrm{LAB}$, and $\mathrm{CB}$, it is suggested that there are numerous potential health benefits exhibited after their consumption if their ABV is as close as possible to $0 \%$. Some of the other suggested health benefits, and the supposed responsible compounds of beer, which still need further particular in-depth investigations, are listed in Figure 2.

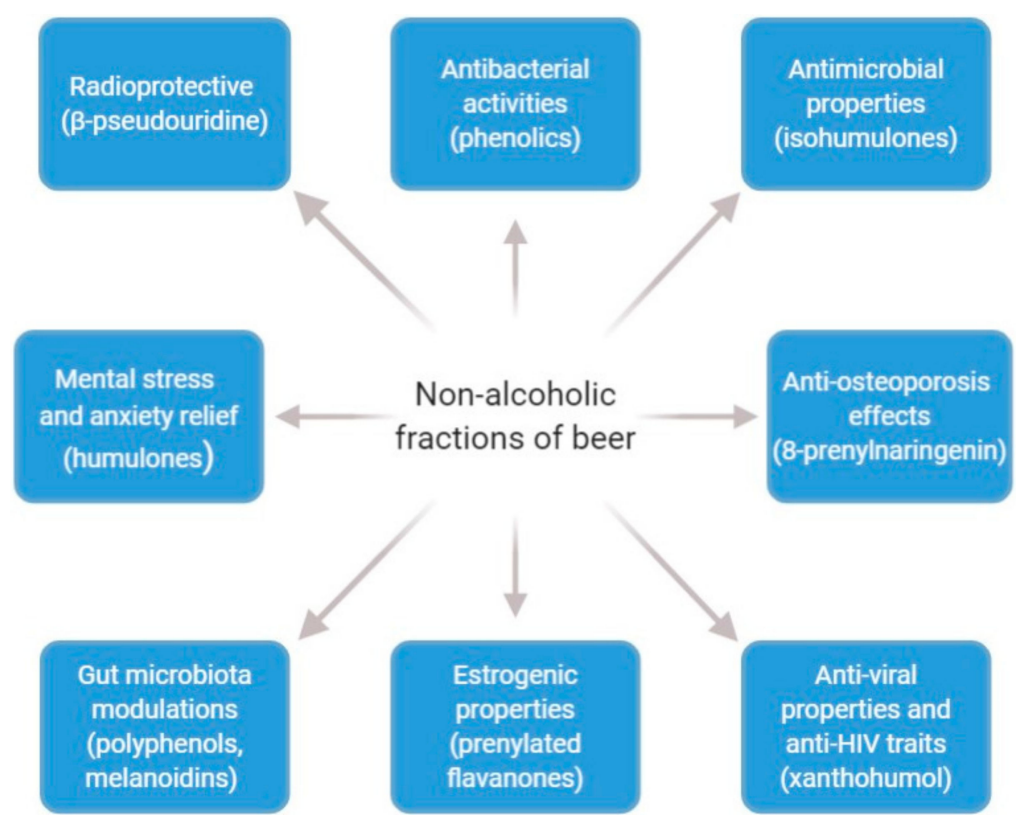

Figure 2. Beneficial properties of beer's nonalcoholic fractions and their supposed responsible compounds, requiring up-to-date in vitro and in vivo studies.

As seen so far, various beer types and some of their compounds were largely studied in in vitro and some in vivo cases of cardiovascular disease and cancer, most likely due to their increasing prevalence and overall mortality risk. However, an increasing number of studies are focused on the impact of beer consumption on highly prevalent diseases. Such an example is a study published in 2019 by Mahli et al. [136], where the therapeutic application of micellar solubilized xanthohumol was evaluated in a western-type diet-induced mouse model of obesity, diabetes, and nonalcoholic fatty liver disease. The core scope of that study was to check if micellar solubilization could increase the therapeutic action and bioavailability of xanthohumol in such diseases.

After feeding the mice with a western-type diet and inducing obesity, diabetes, and nonalcoholic fatty liver disease, the subjects were administered xanthohumol by oral gavage either in the form of micellar solubilizate or as a native extract in a daily dose of $2.5 \mathrm{mg} / \mathrm{kg}$ body weight for 8 weeks. The results indicated that, in contrast with the native extract, the micellar solubilization of xanthohumol significantly inhibited weight gain and hyperglycaemia; reduced hepatic steatosis, pro-inflammatory gene expression (MCP-1 and CXCL1), and immune cell infiltration; as well as reduced the activation of hepatic stellate cells and the expression of collagen alpha I in the livers of mice [136]. Thus, such beer compounds can be selectively harnessed to develop even hepato-protective pharmacological agents with increased benefits over potential risks.

\section{Conclusions}

As presented in this paper, several studies have been performed and focused mainly on the optimization of sensory characteristics and nutritional profile of beers. Still, more investigations are needed to establish a concrete relation between the moderate consumption of special beers and its potential of prevention, amelioration, or the treatment of specific disorders. 
Special beer market is richer than ever, and consumers have begun to pay increasing attention to what they consume. Additional research is key in the development of this sector; along this, there is also the need for continuous creativity in the areas of raw materials, packaging, pricing, and retail availability. This segment will gain new markets and could fulfill the consumers' requirements for products with health-promoting properties.

The nutritional compounds and the health-related perspectives of special beers such as NAB, $\mathrm{LAB}$, and $\mathrm{CBs}$ vary considerably depending on the ingredients used, the production recipe, and overall brewing processes. Nevertheless, certain compounds are commonly available both in regular beers and special beers; therefore, at a certain level, it is safe to claim that all of them have a certain beneficial nutritional impact in one's diet when consumed at moderate levels.

Author Contributions: Conceptualization, L.C.S. and T.E.C.; writing-original draft preparation, M.V.I., L.C.S., C.R.P., T.E.C., and A.B.; writing-review and editing, L.C.S., M.V.I., A.P., and O.A.; supervision, L.C.S., M.T., A.P., E.M., and H.Z.; funding acquisition, L.C.S. All authors have read and agreed to the published version of the manuscript.

Funding: This research was funded by two grants, as follows: from the Ministry of Research and Innovation, CNCS-UEFISCDI, project number PN-III-P2-2.1-CI-2018-1462, within PNCDI III and from the European Foundation for Alcohol Research (ERAB), Belgium, project number Ref EA 1545.

Conflicts of Interest: The authors declare no conflict of interest.

\section{References}

1. Fox, G. The brewing industry and the opportunities for real-time quality analysis using infrared spectroscopy. Appl. Sci. 2020, 10, 616. [CrossRef]

2. Meussdoerffer, F.G. A Comprehensive History of Beer Brewing; Wiley-VCH: Weinheim, Germany, 2009; pp. 1-42.

3. Vieira Humia, B.; Silva Santos, K.; Mendonça Barbosa, A.; Sawata, M.; da Costa Mendonça, M.; Ferreira Padilha, F. Beer molecules and its sensory and biological properties: A review. Molecules 2019, 24, 1568. [CrossRef] [PubMed]

4. Rubio-Flores, M.; Serna-Saldivar, S.O. Technological and engineering trends for production of gluten-free beers. Food Eng. Rev. 2016, 8, 468-482. [CrossRef]

5. Blanco, C.; Nimubona, D.; Fernández-Fernández, E.; Álvarez, I. Sensory characterization of commercial lager beers and their correlations with Iso-alfa-acid Concentrations. J. Food Nutr. Res. 2014, 3, 1-8. [CrossRef]

6. Sánchez-Muniz, F.J.; Macho-Gonzalez, A.; Garcimartín, A.; Santos-López, J.A.; Benedí, J.; Bastida, S.; González-Muñoz, M.J. The nutritional components of beer and its relationship with neurodegeneration and alzheimer's disease. Nutrients 2019, 11, 1558. [CrossRef] [PubMed]

7. Redondo, N.; Nova, E.; Díaz-Prieto, L.E.; Marcos, A. Effects of moderate beer consumption on health. Nutr. Hosp. 2018, 35, 41-44. [CrossRef]

8. Oliveira, N.J.R.; de Oliveira, T.S.; Ghedini, P.C.; Vaz, B.G.; de Souza Gil, E. Antioxidant and vasodilatory activity of commercial beers. J. Funct. Foods 2017, 34, 130-138. [CrossRef]

9. De Gaetano, G.; Costanzo, S.; Di Castelnuovo, A.; Badimon, L.; Bejko, D.; Alkerwi, A.; Chiva-Blanch, G.; Estruch, R.; La Vecchia, C.; Panico, S.; et al. Effects of moderate beer consumption on health and disease: A consensus document. Nutr. Metab. Cardiovasc. Dis. 2016, 26, 443-467. [CrossRef]

10. Franco, L.; Galán, C.; Bravo, R.; Bejarano, I.; Peñas-Lledo, E.; Rodríguez, A.B.; Barriga, C.; Cubero, J. Effect of non-alcohol beer on anxiety: Relationship of 5-HIAA. Neurochem. J. 2015, 9, 149-152. [CrossRef]

11. Oak, M.H.; Auger, C.; Belcastro, E.; Park, S.H.; Lee, H.H.; Schini-Kerth, V.B. Potential mechanisms underlying cardiovascular protection by polyphenols: Role of the endothelium. Free Radic. Biol. Med. 2018, 122, 161-170. [CrossRef]

12. Spaggiari, G.; Cignarelli, A.; Sansone, A.; Baldi, M.; Santi, D. To beer or not to beer: A meta-analysis of the effects of beer consumption on cardiovascular health. PLoS ONE 2020, 15, e0233619. [CrossRef] [PubMed]

13. Martinez-Gomez, A.; Caballero, I.; Blanco, C.A. Phenols and melanoidins as natural antioxidants in beer. Structure, reactivity and antioxidant activity. Biomolecules 2020, 10, 400. [CrossRef] [PubMed] 
14. Wannenmacher, J.; Gastl, M.; Becker, T. Phenolic substances in beer: Structural diversity, reactive potential and relevance for brewing process and beer quality. Compr. Rev. Food Sci. Food Saf. 2018, 17, 953-988. [CrossRef]

15. Koren, D.; Kun, S.; Hegyesné Vecseri, B.; Kun-Farkas, G. Study of antioxidant activity during the malting and brewing process. J. Food Sci. Technol. 2019, 56, 3801-3809. [CrossRef]

16. Pilarski, D.W.; Gerogiorgis, D.I. Progress and modelling of cold contact fermentation for alcohol-free beer production: A review. J. Food Eng. 2020, 273. [CrossRef]

17. Muller, C.; Neves, L.E.; Gomes, L.; Guimarães, M.; Ghesti, G. Processes for alcohol-free beer production: A review. Food Sci. Technol. 2020, 40, 273-281. [CrossRef]

18. The European Parliament and the Council of the European Union EC. The European Parliament and the Council of the European Union Regulation (EU) No 1169/2011 of the European Parliament and of the Council of 25 October 2011 on the provision of food information to consumers, amending Regulations (EC) No 1924/2006 and (EC) No 1925/2006 of the European Parliament and of the Council. Off. J. Eur. Union 2011, 20, 168-213.

19. Brányik, T.; Silva, D.P.; Baszczyňski, M.; Lehnert, R.; Almeida, E.; Silva, J.B. A review of methods of low alcohol and alcohol-free beer production. J. Food Eng. 2012, 108, 493-506. [CrossRef]

20. The European Parliament and the Council of the European Union EC. The European Parliament and the Council of the European Union EC (2006a) Regulation (EC) No 1924/2006 of the European Parliament and of the Council on nutrition and health claims made on foods L 404/9-24. Off. J. Eur. Union 2006, 18, $244-259$.

21. Liguori, L.; De Francesco, G.; Russo, P.; Peretti, G.; Albanese, D.; Di Matteo, M. Production and characterization of alcohol-free beer by membrane process. Food Bioprod. Process. 2015, 94, 158-168. [CrossRef]

22. Salanță, L.C.; Uifălean, A.; Iuga, C.A.; Tofană, M.; Cropotova, J.; Pop, O.L.; Pop, C.R.; Rotar, M.A.; Bautista-Ávila, M.; Velázquez González, C. Valuable food molecules with potential benefits for human health. In The Health Benefits of Foods-Current Knowledge and Further Development; Salanță, L.C., Ed.; InTech: Rijeka, Croatia, 2020; pp. 1-45.

23. Ignat, V.M.; Salanță, L.C.; Pop, O.L.; Pop, C.R.; Tofană, M.; Mudura, E.; Coldea, T.E.; Borșa, A.; Pasqualone, A. Current functionality and potential improvements of non-alcoholic fermented cereal beverages. Foods 2020, 9, 1031. [CrossRef] [PubMed]

24. Horincar, G.; Enachi, E.; Bolea, C.; Râpeanu, G.; Aprodu, I. Value-added lager beer enriched with eggplant (Solanum melongena L.) peel extract. Molecules 2020, 25, 731. [CrossRef] [PubMed]

25. Pereira, I.M.C.; Matos Neto, J.D.; Figueiredo, R.W.; Carvalho, J.D.G.; de Figueiredo, E.A.T.; Santos de Menezes, N.V.; Gaban, S.V.F. Physicochemical characterization, antioxidant activity, and sensory analysis of beers brewed with cashew peduncle (anacardium occidentale) and orange peel (citrus sinensis). Food Sci. Technol. 2020, 40, 749-755. [CrossRef]

26. Đorđević, S.; Popović, D.; Despotović, S.; Veljović, M.; Atanacković, M.; Cvejić, J.; Nedović, V.; Lesko\&šek-Č, I. Extracts of medicinal plants as funcional beer additives. Chem. Ind. Chem. Eng. Q. 2016, 22, 301-308. [CrossRef]

27. Rošul, M.; Mandić, A.; Mišan, A.; Đerić, N.; Pejin, J. Review of trends in formulation of functional beer. Food Feed Res. 2019, 46, 23-35. [CrossRef]

28. Habschied, K.; Živković, A.; Krstanović, V.; Mastanjević, K. Functional beer-A review on possibilities. Beverages 2020, 6, 51. [CrossRef]

29. Sanguansri, L.; Ann, A.M. Microencapsulation in functional food product development. Funct. Food Prod. Dev. 2010, 1-23. [CrossRef]

30. Wootton-Beard, P.C.; Ryan, L. Improving public health?: The role of antioxidant-rich fruit and vegetable beverages. Food Res. Int. 2011, 44, 3135-3148. [CrossRef]

31. Callejo, M.J.; Tesfaye, W.; González, M.C.; Morata, A. Craft Beers: Current Situation and Future Trends. In New Advances on Fermentation Processes; Martínez-Espinosa, R.M., Ed.; IntechOpen: London, UK, 2019; pp. 1-18.

32. Jackowski, M.; Trusek, A. Non-alcoholic beer production-an overview. Pol. J. Chem. Technol. 2018, 20, 32-38. [CrossRef] 
33. De Oliveria, D.M.; Falconi, D. The evolution of craft beer industry in Brazil. J. Econ. Bus. 2018, 1, 618-626. [CrossRef]

34. Punčochářová, L.; Pořízka, J.; Diviš, P.; Štursa, V. Study of the influence of brewing water on selected analytes in beer. Potravin. Slovak J. Food Sci. 2019, 13, 507-514. [CrossRef]

35. Okolo, B.N.; Amadi, O.C.; Moneke, A.N.; Nwagu, T.N.; Nnamchi, C.I. Influence of malted barley and exogenous enzymes on the glucose/maltose balance of worts with sorghum or barley as an adjunct. J. Inst. Brew. 2020, 126, 46-52. [CrossRef]

36. Buratti, S.; Benedetti, S. Alcoholic Fermentation Using Electronic Nose and Electronic Tongue. In Electronic Noses and Tongues in Food Science. In Electronic Noses and Tongues in Food Science; Elsevier: Amsterdam, The Netherlands, 2016; pp. 291-299.

37. Cela, N.; Condelli, N.; Caruso, M.C.; Perretti, G.; Di Cairano, M.; Tolve, R.; Galgano, F. Gluten-free brewing: Issues and perspectives. Fermentation 2020, 6, 53. [CrossRef]

38. Capece, A.; Romaniello, R.; Pietrafesa, A.; Siesto, G.; Pietrafesa, R.; Zambuto, M.; Romano, P. Use of saccharomyces cerevisiae var. boulardii in co-fermentations with s. cerevisiae for the production of craft beers with potential healthy value-added. Int. J. Food Microbiol. 2018, 284, 22-30. [CrossRef] [PubMed]

39. Boronat, A.; Soldevila-Domenech, N.; Rodríguez-Morató, J.; Martínez-Huélamo, M.; Lamuela-Raventós, R.M.; de la Torre, R. Beer phenolic composition of simple phenols, prenylated flavonoids and alkylresorcinols. Molecules 2020, 25, 2582. [CrossRef] [PubMed]

40. Salanță, L.C.; Coldea, T.E.; Ignat, M.V.; Pop, C.R.; Tofană, M.; Mudura, E.; Borșa, A.; Pasqualone, A.; Haifeng, Z. Non-alcoholic and craft beer production and challenges. Processes 2020, 8, 1382. [CrossRef]

41. Zhao, H.; Li, H.; Sun, G.; Yang, B.; Zhao, M. Assessment of endogenous antioxidative compounds and antioxidant activities of lager beers. J. Sci. Food Agric. 2013, 93, 910-917. [CrossRef]

42. Padro, T.; Muñoz-García, N.; Vilahur, G.; Chagas, P.; Deyà, A.; Antonijoan, R.M.; Badimon, L. Moderate beer intake and cardiovascular health in overweight individuals. Nutrients 2018, 10, 1237. [CrossRef]

43. Nardini, M.; Garaguso, I. Characterization of bioactive compounds and antioxidant activity of fruit beers. Food Chem. 2020, 305, 125437. [CrossRef]

44. Vieira Humia, B.; Silva Santos, K.; Schneider, J.K.; Leal, I.L.; de Abreu, B.G.; Batista, T.; Machado, B.A.S.; Druzian, J.I.; Krause, L.C.; da Costa Mendonça, M.; et al. Physicochemical and sensory profile of beauregard sweet potato beer. Food Chem. 2020, 312, 126087. [CrossRef]

45. Parkin, E.; Shellhammer, T. Toward understanding the bitterness of dry-hopped beer. J. Am. Soc. Brew. Chem. 2017, 75, 363-368. [CrossRef]

46. Salanță, L.C.; Tofană, M.; Socaci, S.; Pop, A.; Odagiu, A.N.M.; Cuceu, A. Evaluation of volatile compounds from hüller bitterer variety grown in Romania by chemometric methods. J. Agroaliment. Process. Technol. 2015, 21, 231-236.

47. Mudura, E.; Coldea, T. Hop-derived prenylflavonoids and their importance in brewing technology: A Review. Bull. Uasvm Food Sci. Technol. 2015, 72, 1-10. [CrossRef]

48. Michiu, D.; Socaci, S.A.; Jimborean, M.A.; Mudura, E.; Fărcaş, A.C.; Biriş-Dorhoi, S.E.; Tofană, M. Determination of volatile markers from magnum hops in beer by in-tube extraction-Gas chromatography-Mass spectrometry. Anal. Lett. 2018, 51, 2967-2980. [CrossRef]

49. Salanță, L.C.; Socaci, S.A.; Tofană, M.; Mudura, E.; Pop, C.R.; Nagy, M.; Odagiu, A. Characterization of volatile components in hop pellets using in-tube extraction GC-MS analysis. Rom. Biotechnol. Lett. 2018, 23, 13541-13550.

50. Hrnčič, M.K.; Španinger, E.; Košir, I.J.; Knez, Ž.; Bren, U. Hop compounds: Extraction techniques, chemical analyses, antioxidative, antimicrobial, and anticarcinogenic effects. Nutrients 2019, 11, 257. [CrossRef]

51. Salanţă, L.C.; Tofană, M.; Socaci, S.; Mudura, E.; Fărcaş, A.; Pop, C.; Pop, A.; Odagiu, A. Characterisation of hop varieties grown in romania based on their contents of bitter acids by HPLC in combination with chemometrics approach. Czech J. Food Sci. 2015, 33, 148-155. [CrossRef]

52. De Francesco, G.; Marconi, O.; Sileoni, V.; Freeman, G.; Lee, E.G.; Floridi, S.; Perretti, G. Influence of the dealcoholisation by osmotic distillation on the sensory properties of different beer types. J. Food Sci. Technol. 2020. Available online: https://link.springer.com/article/10.1007\%2Fs13197-020-04662-5 (accessed on 9 September 2020). [CrossRef] 
53. Lawton, M.R.; Alcaine, S.D. Leveraging endogenous barley enzymes to turn lactose-containing dairy by-products into fermentable adjuncts for saccharomyces cerevisiae-based ethanol fermentations. J. Dairy Sci. 2019, 102, 2044-2050. [CrossRef]

54. Bamforth, C.W. Beer styles and recipe development: What should I brew? In The Craft Brewing Handbook: A Practical Guide to Running a Successful Craft Brewery; Smart, C., Ed.; Woodhead Publishing: Duxford, UK, 2020; pp. 47-63.

55. Facioni, M.S.; Raspini, B.; Pivari, F.; Dogliotti, E.; Cena, H. Nutritional management of lactose intolerance: The importance of diet and food labelling. J. Transl. Med. 2020, 1-9. [CrossRef]

56. Adamenko, K.; Kawa-rygielska, J.; Kucharska, A.Z. Characteristics of cornelian cherry sour non-alcoholic beers brewed with the special yeast saccharomycodes ludwigii. Food Chem. 2020, 312, 125968. [CrossRef]

57. Ricci, A.; Cirlini, M.; Guido, A.; Liberatore, C.M.; Ganino, T.; Lazzi, C.; Chiancone, B. From byproduct to resource: Fermented apple pomace as beer flavoring. Foods 2019, 8, 309. [CrossRef]

58. Gasiński, A.; Kawa-Rygielska, J.; Szumny, A.; Gąsior, J.; Głowacki, A. Assessment of volatiles and polyphenol content, physicochemical parameters and antioxidant activity in beers with dotted hawthorn (crataegus punctata). Foods 2020, 9, 775. [CrossRef] [PubMed]

59. Gasiński, A.; Kawa-Rygielska, J.; Szumny, A.; Czubaszek, A.; Gąsior, J.; Pietrzak, W. Volatile compounds content, physicochemical parameters, and antioxidant activity of beers with addition of mango fruit (mangifera indica). Molecules 2020, 25, 3033. [CrossRef] [PubMed]

60. Mellor, D.D.; Hanna-Khalil, B.; Carson, R. A review of the potential health benefits of low alcohol and alcohol-free beer: Effects of ingredients and craft brewing processes on potentially bioactive metabolites. Beverages 2020, 6, 25. [CrossRef]

61. Carvalho, F.R.; Moors, P.; Wagemans, J.; Spence, C. The influence of color on the consumer's experience of beer. Front. Psychol. 2017, 8, 1-9. [CrossRef]

62. Reinoso-Carvalho, F.; Dakduk, S.; Wagemans, J.; Spence, C. Dark vs. light drinks: The influence of visual appearance on the consumer's experience of beer. Food Qual. Prefer. 2019, 74, 21-29. [CrossRef]

63. Stachová, I.; Lhotská, I.; Solich, P.; Šatínský, D. Determination of green, blue and yellow artificial food colorants and their abuse in herb-coloured green easter beers on tap. Food Addit. Contam. Part A 2016, 33, 1139-1146. [CrossRef]

64. Jahn, A.; Kim, J.; Bashir, K.M.I.; Cho, M. Antioxidant content of aronia infused beer. Fermentation 2020, 6, 71. [CrossRef]

65. Romero-Medina, A.; Estarrón-Espinosa, M.; Verde-Calvo, J.R.; Lelièvre-Desmas, M.; Escalona-Buendía, H.B. Renewing traditions: A sensory and chemical characterisation of mexican pigmented corn beers. Foods 2020, 9, 886. [CrossRef]

66. Vanderhaegen, B.; Neven, H.; Verachtert, H.; Derdelinckx, G. The chemistry of beer aging-a critical review. Food Chem. 2006, 95, 357-381. [CrossRef]

67. Krebs, G.; Müller, M.; Becker, T.; Gastl, M. Characterization of the macromolecular and sensory profile of non-alcoholic beers produced with various methods. Food Res. Int. 2019, 116, 508-517. [CrossRef] [PubMed]

68. Devolli, A.; Dara, F.; Stafasani, M.; Shahinasi, E.; Kodra, M. The influence of protein content on beer quality and colloidal stability. Int. J. Innov. Approaches Agric. Res. 2018, 2, 391-407. [CrossRef]

69. Gorinstein, S.; Zemser, M.; Vargas-Albores, F.; Ochoa, J.L.; Paredes-Lopez, O.; Scheler, C.; Salnikow, J.; Martin-Belloso, O.; Trakhtenberg, S. Proteins and amino acids in beers, their contents and relationships with other analytical data. Food Chem. 1999, 67,71-78. [CrossRef]

70. Silva, A.P.; Jager, G.; Voss, H.P.; van Zyl, H.; Hogg, T.; Pintado, M.; de Graaf, C. What's in a name? The effect of congruent and incongruent product names on liking and emotions when consuming beer or non-alcoholic beer in a bar. Food Qual. Prefer. 2017, 55, 58-66. [CrossRef]

71. Sohrabvandi, S.; Mortazavian, A.M.; Rezaei, K. Health-related aspects of beer: A review. Int. J. Food Prop. 2012, 15, 350-373. [CrossRef]

72. Decloedt, A.I.; van Landschoot, A.; Watson, H.; Vanderputten, D.; Vanhaecke, L. Plant-based beverages as good sources of free and glycosidic plant sterols. Nutrients 2018, 10, 21. [CrossRef]

73. Gordon, R.; Power, A.; Chapman, J.; Chandra, S.; Cozzolino, D. A review on the source of lipids and their interactions during beer fermentation that affect beer quality. Fermentation 2018, 4, 89. [CrossRef]

74. Bravi, E.; Marconi, O.; Sileoni, V.; Perretti, G. Determination of free fatty acids in beer. Food Chem. 2017, 215, 341-346. [CrossRef] 
75. Bogdan, P.; Kordialik-Bogacka, E.; Czyżowska, A.; Oracz, J.; Żyżelewicz, D. The profiles of low molecular nitrogen compounds and fatty acids in wort and beer obtained with the addition of quinoa (chenopodium quinoa willd.), amaranth (Amaranthus cruentus L.) or maltose syrup. Foods 2020, 9, 1626. [CrossRef]

76. Lordan, R.; O'Keeffe, E.; Tsoupras, A.; Zabetakis, I. Total, neutral, and polar lipids of brewing ingredients, by-products and beer: Evaluation of antithrombotic activities. Foods 2019, 8, 171. [CrossRef]

77. Lordan, R.; O’Keeffe, E.; Dowling, D.; Mullally, M.; Heffernan, H.; Tsoupras, A.; Zabetakis, I. The in vitro antithrombotic properties of ale, lager, and stout beers. Food Biosci. 2019, 28, 83-88. [CrossRef]

78. Bamforth, C.W. Nutritional aspects of beer-a review. Nutr. Res. 2002, 22, 227-237. [CrossRef]

79. Díaz-Rubio, M.E.; Saura-Calixto, F. Dietary fiber complex in beer. J. Am. Soc. Brew. Chem. 2009, 67, $38-43$. [CrossRef]

80. Bustos, L.; Soto, E.; Parra, F.; Echiburu-Chau, C.; Parra, C. Brewing of a porter craft beer enriched with the plant parastrephia lucida: A promising source of antioxidant compounds. J. Am. Soc. Brew. Chem. 2019, 77, 261-266. [CrossRef]

81. Johnson, S.R.; Soprano, S.E.; Wickham, L.M.; Fitzgerald, N.; Edwards, J.C. Nuclear magnetic resonance and headspace solid-phase microextraction gas chromatography as complementary methods for the analysis of beer samples. Beverages 2017, 3, 21. [CrossRef]

82. Osorio-Paz, I.; Brunauer, R.; Alavez, S. Beer and its non-alcoholic compounds in health and disease. Crit. Rev. Food Sci. Nutr. 2019, 1-14. [CrossRef]

83. European Food Safety Authority (EFSA). Overview on Dietary Reference Values for the EU population as derived by the EFSA Panel on Dietetic Products, Nutrition and Allergies (NDA). In Summary of Dietary Reference Values, version 4; EFSA: Parma, Italy, 2017; pp. 1-15.

84. Olšovská, J.; Štěrba, K.; Pavlovič, M.; Čejka, P. Determination of the energy value of beer. J. Am. Soc. Brew. Chem. 2015, 73, 165-169. [CrossRef]

85. Ramos-Peralonso, M.J. European Food Safety Authority (EFSA) Scientific Opinion on Dietary Reference Values for energy. EFSA J. 2013, 11, 20. [CrossRef]

86. Moreira, S.; Vives, A.E.S.; Zucchi, O.L.A.D.; de Jesus, E.F.O.; Nascimento Filho, V.F.; Brienza, S.M.B. Analysis of beers from Brazil with synchrotron radiation total reflection X-ray fluorescence. J. Radioanal. Nucl. Chem. 2006, 270, 167-171. [CrossRef]

87. Fernández-Solà, J. Cardiovascular risks and benefits of moderate and heavy alcohol consumption. Nat. Rev. Cardiol. 2015, 12, 576-587. [CrossRef]

88. Piazzon, A.; Forte, M.; Nardini, M. Characterization of phenolics content and antioxidant activity of different beer types. J. Agric. Food Chem. 2010, 58, 10677-10683. [CrossRef] [PubMed]

89. Nogueira, L.C.; do Rio, R.F.; Lollo, P.C.B.; Ferreira, I.M.P.L.V.O. Moderate alcoholic beer consumption: The effects on the lipid profile and insulin sensitivity of adult men. J. Food Sci. 2017, 82, 1720-1725. [CrossRef] [PubMed]

90. Quesada-Molina, M.; Muñoz-Garach, A.; Tinahones, F.J.; Moreno-Indias, I. A new perspective on the health benefits of moderate beer consumption: Involvement of the gut microbiota. Metabolites 2019, 9, 272. [CrossRef] [PubMed]

91. Deželak, M.; Zarnkow, M.; Becker, T.; Košir, I.J. Processing of bottom-fermented gluten-free beer-like beverages based on buckwheat and quinoa malt with chemical and sensory characterization. J. Inst. Brew. 2014, 120, 360-370. [CrossRef]

92. Gorinstein, S.; Caspi, A.; Libman, I.; Leontowicz, H.; Leontowicz, M.; Tashma, Z.; Katrich, E.; Jastrzebski, Z.; Trakhtenberg, S. Bioactivity of beer and its influence on human metabolism. Int. J. Food Sci. Nutr. 2007, 58, 94-107. [CrossRef]

93. Gorjanović, S.Ž.; Novaković, M.M.; Potkonjak, N.I.; Ida, L.Č.; Sužnievič, D.Ž. Application of a novel antioxidative assay in beer analysis and brewing process monitoring. J. Agric. Food Chem. 2010, 58, 744-751. [CrossRef]

94. Gasior, J.; Kawa-Rygielska, J.; Kucharska, A.Z. Carbohydrates profile, polyphenols content and antioxidative properties of beer worts produced with different dark malts varieties or roasted barley grains. Molecules 2020, 25, 3882. [CrossRef]

95. Saura-Calixto, F.; Serrano, J.; Pérez-Jiménez, J. What contribution is beer to the intake of antioxidants in the diet? In Beer in Health and Disease Prevention; Elsevier: Amsterdam, The Netherlands, 2008; pp. 441-448. 
96. Schwarz, K.J.; Boitz, L.I.; Methner, F.J. Release of phenolic acids and amino acids during mashing dependent on temperature, ph, time, and raw materials. J. Am. Soc. Brew. Chem. 2012, 70, 290-295. [CrossRef]

97. Zhao, H. Effects of Processing Stages on the Profile of Phenolic Compounds in Beer; Elsevier: Amsterdam, The Netherlands, 2015; pp. 533-539.

98. Pascoe, H.M.; Ames, J.M.; Chandra, S. Critical stages of the brewing process for changes in antioxidant activity and levels of phenolic compounds in ale. J. Am. Soc. Brew. Chem. 2004, 61, 203-209. [CrossRef]

99. Fumi, M.D.; Galli, R.; Lambri, M.; Donadini, G.; De Faveri, D.M. Effect of full-scale brewing process on polyphenols in Italian all-malt and maize adjunct lager beers. J. Food Compos. Anal. 2011, 24, 568-573. [CrossRef]

100. Ambrož, M.; Lněničková, K.; Matoušková, P.; Skálová, L.; Boušová, I. Antiproliferative effects of hop-derived prenylflavonoids and their influence on the efficacy of oxaliplatine, 5-fluorouracil and irinotecan in human colorectalC cells. Nutrients 2019, 11, 879. [CrossRef] [PubMed]

101. Leskošek-Čukalović, I.; Despotović, S.; Nedović, V.; Lakić, N.; Nikšić, M. New type of beer-Beer with improved functionality and defined pharmacodynamic properties. Food Technol. Biotechnol. 2010, 48, 384-391.

102. Ducruet, J.; Rébénaque, P.; Diserens, S.; Kosińska-Cagnazzo, A.; Héritier, I.; Andlauer, W. Amber ale beer enriched with goji berries-The effect on bioactive compound content and sensorial properties. Food Chem. 2017, 226, 109-118. [CrossRef] [PubMed]

103. Cumaoglu, A.; Bekci, H.; Ozturk, E.; Yerer, M.B.; Baldemir, A.; Bishayee, A. Goji berry fruit extracts suppress proliferation of triple-negative breast cancer cells by inhibiting EGFR-Mediated ERK/MAPK and PI3K/Akt signaling pathways. Nat. Prod. Commun. 2018, 13, 701-706. [CrossRef]

104. Deng, Y.; Lim, J.; Nguyen, T.T.H.; Mok, I.K.; Piao, M.; Kim, D. Composition and biochemical properties of ale beer enriched with lignans from schisandra chinensis baillon (omija) fruits. Food Sci. Biotechnol. 2020, 29, 609-617. [CrossRef]

105. Gumienna, M.; Górna, B. Gluten hypersensitivities and their impact on the production of gluten-free beer. Eur. Food Res. Technol. 2020, 246, 2147-2160. [CrossRef]

106. Holasova, M.; Fiedlerova, V.; Smrcinova, H.; Orsak, M.; Lachman, J.; Vavreinova, S. Buckwheat-the source of antioxidant activity in functional foods. Food Res. Int. 2002, 35, 207-211. [CrossRef]

107. Hu, Y.; Zhang, J.; Zou, L.; Fu, C.; Li, P.; Zhao, G. Chemical characterization, antioxidant, immune-regulating and anticancer activities of a novel bioactive polysaccharide from chenopodium quinoa seeds. Int. J. Biol. Macromol. 2017, 99, 622-629. [CrossRef]

108. Tang, Y.; Li, X.; Chen, P.X.; Zhang, B.; Hernandez, M.; Zhang, H.; Marcone, M.F.; Liu, R.; Tsao, R. Characterisation of Fatty Acid, Carotenoid, Tocopherol/Tocotrienol Compositions and Antioxidant Activities in Seeds of Three Chenopodium Quinoa Willd. Genotypes; Elsevier: Amsterdam, The Netherlands, 2015; pp. 502-508.

109. Eggum, B.O.; Kreft, I.; Javornik, B. Chemical composition and protein quality of buckwheat (fagopyrum esculentum moench). Qual. Plant. Plant. Foods Hum. Nutr. 1980, 30, 175-179. [CrossRef]

110. Nowak, V.; Du, J.; Charrondière, U.R. Assessment of the nutritional composition of quinoa (chenopodium quinoa willd.). Food Chem. 2016, 193, 47-54. [CrossRef]

111. Taylor, J.R.N.; Dlamini, B.C.; Kruger, J. 125th anniversary review: The science of the tropical cereals sorghum, maize and rice in relation to lager beer brewing. J. Inst. Brew. 2013, 119, 1-14. [CrossRef]

112. Kerpes, R.; Fischer, S.; Becker, T. The production of gluten-free beer: Degradation of hordeins during malting and brewing and the application of modern process technology focusing on endogenous malt peptidases. Trends Food Sci. Technol. 2017, 67, 129-138. [CrossRef]

113. Yang, Y.; Li, S.; Zhang, K.; Dong, Z.; Li, Y.; An, X.; Chen, J.; Chen, Q.; Jiao, Z.; Liu, X.; et al. Efficient isolation of ion beam-induced mutants for homoeologous loci in common wheat and comparison of the contributions of Glu-1 loci to gluten functionality. Appl. Genet. 2013, 127, 359-372. [CrossRef] [PubMed]

114. Guerdrum, L.J.; Bamforth, C.W. Prolamin levels through brewing and the impact of prolyl endoproteinase. J. Am. Soc. Brew. Chem. 2012, 70, 35-38. [CrossRef]

115. Yeo, H.Q.; Liu, S.Q. An overview of selected specialty beers: Developments, challenges and prospects. Int. J. Food Sci. Technol. 2014, 49, 1607-1618. [CrossRef]

116. Vinson, J.A.; Mandarano, M.; Hirst, M.; Trevithick, J.R.; Bose, P. Phenol antioxidant quantity and quality in foods: Beers and the effect of two types of beer on an animal model of atherosclerosis. J. Agric. Food Chem. 2003, 51, 5528-5533. [CrossRef] [PubMed] 
117. Zapata, P.J.; Martínez-Esplá, A.; Gironés-Vilaplana, A.; Santos-Lax, D.; Noguera-Artiaga, L.; Carbonell-Barrachina, Á.A. Phenolic, volatile, and sensory profiles of beer enriched by macerating quince fruits. LWT 2019, 103, 139-146. [CrossRef]

118. Sterczyńska, M.; Stachnik, M.; Poreda, A.; Pużyńska, K.; Piepiórka-Stepuk, J.; Fiutak, G.; Jakubowski, M. Ionic composition of beer worts produced with selected unmalted grains. LWT 2020, 110348. [CrossRef]

119. Alves, V.; Gonçalves, J.; Figueira, J.A.; Ornelas, L.P.; Branco, R.N.; Câmara, J.S.; Pereira, J.A.M. Beer volatile fingerprinting at different brewing steps. Food Chem. 2020, 326, 126856. [CrossRef]

120. Anderson, H.E.; Santos, I.C.; Hildenbrand, Z.L.; Schug, K.A. A review of the analytical methods used for beer ingredient and finished product analysis and quality control. Anal. Chim. Acta 2019, 1085, 1-20. [CrossRef]

121. Gerhauser, C. Beer constituents as potential cancer chemopreventive agents. Eur. J. Cancer 2005, 41, 1941-1954. [CrossRef] [PubMed]

122. Habschied, K.; Loncarić, A.; Mastanjević, K. Screening of polyphenols and antioxidative activity in industrial beers. Foods 2020, 9, 238. [CrossRef]

123. Styburski, D.; Janda, K.; Baranowska-Bosiacka, I.; Łukomska, A.; Dec, K.; Goschorska, M.; Michalkiewicz, B.; Ziettek, P.; Gutowska, I. Beer as a potential source of macroelements in a diet: The analysis of calcium, chlorine, potassium, and phosphorus content in a popular low-alcoholic drink. Eur. Food Res. Technol. 2018, 244, 1853-1860. [CrossRef]

124. Soetan, K.O.; Olaiya, C.O.; Oyewole, O.E. The importance of mineral elements for humans, domestic animals and plants: A review. Afr. J. Food Sci. 2010, 4, 200-222.

125. Scalbert, A.; Manach, C.; Morand, C.; Rémésy, C.; Jiménez, L. Dietary polyphenols and the prevention of diseases. Crit. Rev. Food Sci. Nutr. 2005, 45, 287-306. [CrossRef] [PubMed]

126. Alkhaldy, A.A.; Alamri, R.S.; Magadmi, R.K.; Elshini, N.Y.; Hussein, R.A.E.H.; Alghalayini, K.W. Dietary adherence of saudi males to the saudi dietary guidelines and its relation to cardiovascular diseases: A preliminary cross-sectional study. JCDD 2019, 6, 17. [CrossRef] [PubMed]

127. Bassus, S.; Mahnel, R.; Scholz, T.; Wegert, W.; Westrup, D.; Kirchmaier, C.M. Effect of dealcoholized beer (bitburger drive) consumption on hemostasis in humans. Alcohol Clin. Exp. Res. 2004, 28, 786-791. [CrossRef] [PubMed]

128. Chiva-Blanch, G.; Magraner, E.; Condines, X.; Valderas-Martínez, P.; Roth, I.; Arranz, S.; Casas, R.; Navarro, M.; Hervas, A.; Sisó, A.; et al. Effects of alcohol and polyphenols from beer on atherosclerotic biomarkers in high cardiovascular risk men: A randomized feeding trial. Nutr. Metab. Cardiovasc. Dis. 2015, 25, 36-45. [CrossRef]

129. Alvarez, J.R.M.; Bellés, V.V.; López-Jaén, A.B.; Marín, A.V.; Codoñer-Franch, P. Effects of alcohol-free beer on lipid profile and parameters of oxidative stress and inflammation in elderly women. Nutrition 2009, 25, 182-187. [CrossRef]

130. George, V.C.; Dellaire, G.; Rupasinghe, H.P.V. Plant flavonoids in cancer chemoprevention: Role in genome stability. J. Nutr. Biochem. 2017, 45, 1-14. [CrossRef]

131. Vanhoecke, B.; Derycke, L.; Van Marck, V.; Depypere, H.; De Keukeleire, D.; Bracke, M. Antiinvasive effect of xanthohumol, a prenylated chalcone present in hops (Humulus lupulus L.) and beer. Int. J. Cancer 2005, 117, 889-895. [CrossRef] [PubMed]

132. Modak, S.; Kushner, B.H.; Kramer, K.; Vickers, A.; Cheung, I.Y.; Cheung, N.K.V. Anti-GD2 antibody 3F8 and barley-derived $(1 \rightarrow 3),(1 \rightarrow 4)-\beta$-D-glucan: A phase i study in patients with chemoresistant neuroblastoma. Oncoimmunology 2013, 2, 37-41. [CrossRef] [PubMed]

133. Hernández-Quiroz, F.; Nirmalkar, K.; Villalobos-Flores, L.E.; Murugesan, S.; Cruz-Narváez, Y.; Rico-Arzate, E.; Hoyo-Vadillo, C.; Chavez-Carbajal, A.; Pizano-Zárate, M.L.; García-Mena, J. Influence of moderate beer consumption on human gut microbiota and its impact on fasting glucose and $\beta$-cell function. Alcohol 2020, 85, 77-94. [CrossRef] [PubMed]

134. Merino, P.; Santos-López, J.A.; Mateos, C.J.; Meseguer, I.; Garcimartín, A.; Bastida, S.; Sánchez-Muniz, F.J.; Benedí, J.; González-Muñoz, M.J. Can nonalcoholic beer, silicon and hops reduce the brain damage and behavioral changes induced by aluminum nitrate in young male Wistar rats? Food Chem. Toxicol. 2018, 118, 784-794. [CrossRef] 
135. Castro-Sepulveda, M.; Johannsen, N.; Astudillo, S.; Jorquera, C.; Álvarez, C.; Zbinden-Foncea, H.; Ramírez-Campillo, R. Effects of beer, non-alcoholic beer and water consumption before exercise on fluid and electrolyte homeostasis in athletes. Nutrients 2016, 8, 345. [CrossRef]

136. Mahli, A.; Seitz, T.; Freese, K.; Frank, J.; Weiskirchen, R.; Abdel-Tawab, M.; Behnam, D.; Hellerbrand, C. Therapeutic application of micellar solubilized liver disease. Cells 2019, 8, 359. [CrossRef]

Publisher's Note: MDPI stays neutral with regard to jurisdictional claims in published maps and institutional affiliations.

(C) 2020 by the authors. Licensee MDPI, Basel, Switzerland. This article is an open access article distributed under the terms and conditions of the Creative Commons Attribution (CC BY) license (http://creativecommons.org/licenses/by/4.0/). 